\title{
PUBLIC REGULATION OF DOMESTIC AIRLINES: A PROPOSAL FOR STRUCTURAL AND SUBSIDY REFORM
}

Although domestic airlines serve the transportation needs of millions, ${ }^{1}$ this major industry ${ }^{2}$ is not self-supporting. Heavy government aid, both direct and indirect, flows to the lines annually. ${ }^{3}$ Financial assistance coupled with Civil Aeronautics Board control aims to promote growth of a healthy air transportation system. ${ }^{4}$ But this regulatory scheme does not match the typical public utility pattern of tightly regulated monopoly. ${ }^{5}$ Instead, it is hybridpart government control and part government-inspired competition. And while tweive years of regulation and monetary aid have clearly fostered growth, ${ }^{6}$ the industry structure today is far from sound.

\section{Development of Regulation and Aid}

Comprehensive airline regulation began in $1938^{7}$ when air transport was more an experiment than a service. Economic instabilities and loose operational practices plagued the industry. ${ }^{8}$ Chaotic airline conditions thwarted the public interest in efficient air transport and led to the passage of a Civil

1. Domestic scheduled airlines carried more than 17 million passengers in 1950. Aviation Week, Feb. 26, 1951, p. 110.

2. In 1950 the domestic scheduled lines had assets of $\$ 542$ million and employed 62,000 persons. Ibid. In the same year total operating revenues were $\$ 558$ million. Id., April 9, 1951, p. 16.

3. See notes 45-52 infra and text.

4. See, e.g., the Civil Aeronautics Act's declaration of policy. 52 Stat. 973, 980 (1938), 49 U.S.C. $\$ 402$ (1946).

5. In typical public utilities, regulation is a substitute for competition because the regulated company is the only seller in a market. The regulatory body controls the utility's rates to assure it a fair return on its investment. See Hearings, infra note 21 at 2119 .

6. Between 1938 and 1950 passenger miles flown have increased $1400 \%$, assets $1500 \%$, available seat miles $1700 \%$, and revenues $1300 \%$. Computed from statistics in: Aviation Week, Feb. 26, 1951, p. 10; American Aviation, April 16, 1951, p. 6; CAB, Annual AIRline Statistics (1943); Air Transport Association of America-Airuine Finance and Accounting Conference, Conparative Statemient of Air Carrter Assets, Liabilities and Capital as of Dec. 31, 1950; Air Transport Assoctation of AMrericaAirline Finance and Accounting Conference, Comparative Statement of Air Carrier Income and Expenses, 12 Months Ending Deceniber 31, 1950.

7. Regulation prior to 1938 was a hodgepodge based on several different statutes and under the control of various branches of the government. For an excellent summary of pre-1938 regulation, see Ballard, Federal Regulation of Aviation, 60 HARv. L. REv. 1235, 1235-52 (1947). In general, legislation prior to the Civil Aeronautics Act was concerned chiefly with air mail. Ibid.

8. See Comment, 57 YaLE L.J. 1053, 1055 (1948); note 26 infra. 
Aeronautics Act in 1938.9 Virtually complete economic supervision of the airlines, along with safety and operational control, ${ }^{10}$ became the task of a newly created government agency. ${ }^{11}$ The Act also provides for a federal subsidy in the form of mail payments based on need rather than performance and leaves determination of need to the CAB. ${ }^{12}$

\section{Structural Regulation}

Though under the Act the Board may not automatically bar new entrants from the industry, ${ }^{13}$ its action on applications for new services has in effect restricted the industry to those firms in successful operation in 1938. ${ }^{14}$ Certification of "feeder" lines and post-war entry of large non-scheduled carriers are the sole exceptions. ${ }^{15}$

"Feeder" lines serve outlying, short-haul areas and complement rather than compete with the trunk lines. ${ }^{16}$ Because no efficient short-haul airplane

9. See, e.g., In re Large Irregular Carrier Individual Exemptions, C.A.B. Serial No. E-4240-52, May 25, 1950, p. 2 (mimeo), and the Civil Aeronautics Act's declaration of policy, 52 Stat. 973, 980 (1938), 49 U.S.C. \& 402 (1946).

10. For an examination of these powers and comparison with other transportation regulatory agencies, see Dearing \& Owen, National Transportation Policy 196 et seq. (1949).

11. Under Reorganization Plan IV (1940), 54 STat. 1235 (1940), 5 U.S.C. $\$ 133(t)$ (1946), the Civil Aeronautics Authority (initially established to administer the Act) was consolidated with the Air Safety Board. The merged body which now administers the Act was designated the Civil Aeronautics Board, hereinafter called the Board.

12. $\$ \S 406$ (a) \& (b) of the Act. 52 Srat. 973,998 (1938), 49 U.S.C. $\$ 486$ (1946).

13. $\$ 401$ (d) (1) of the Act provides that the Board issue a certificate of convenience and necessity for any operation "if it finds that the applicant is fit, willing, and able to perform such transportation properly, ... and that such transportation is required by the public convenience and necessity." 52 STAT. 973, 987 (1938), 49 U.S.C. $\$ 481$ (1946).

14. For criticism of the CAB's exclusionary policies, see Comment 57 YalE L.J. 1053, 1061 (1948). See Westwood, Choice of the Air Carricr for New Air Transport Routes, 16 GEo. WASH. L. REv. 1 (1947) for new route certification criteria.

The "grandfather clause" of the Act, $\S 401$ (e) (1) was a statutory basis for closing the industry. The clause provides that carriers in operation at the time of the statute's enactment be certified unless their operations were not justified by public convenience and necessity. In effect it created a presumption in favor of existing carriers. For the view that the clause discouraged $\mathrm{CAB}$ route restructuring, see Landis, Air Rontes under the Civil Aeronautics Act, 15 J. ARR L. 295 (1948). Prior to the Act, competitive bidding for air mail contracts fixed the route pattern. Ibid.

15. See Comment, 57 YaLE L.J. 1053, 1062 (1948). Except for certified feeders, notes 16-21 infra and text, and exempted non-scheds, notes 20-31 infra and text, the members of the industry today are substantially the same as in 1938. See CAB ANNund Report app. B-1 (1939); CAB, Annual Report app. A (1949).

Established carriers have successfully intervened in new certification hearings where certification was denied. E.g., Trans-Southern Airlines, Inc., 2 CAB 250 (1940).

16. See generally, CAB, ANNuAL REPoRT 4 (1947) ; Investigation of Local, Feeder and Pick-up Air Service, 6 C.A.B. 1 (1944). At present, seventeen certificated feeders are in operation. Aviation Week, Feb. 26, 1951, p. 110. Since only one feeder operates in a given area, feeders do not compete with each other. See National Feeder Airline Map. CAB, AnNual Report app. B (1949). 
has been developed, ${ }^{17}$ all "feeders" are heavily subsidized. ${ }^{18}$ They are treated frankly as an experiment by the Board, ${ }^{19}$ hold only temporary certificates, ${ }^{20}$ and represent but a small segment of the industry.21

Non-scheduled carriers have always supplied passenger flights. ${ }^{22}$ Fixed base operators, ${ }^{23}$ long engaged in incidental charter operations with small aircraft, have provided minor non-scheduled services. But when enthusiastic war-trained entrepreneurs flying surplus transport aircraft entered the field, non-scheduled flying became a significant operation. ${ }^{24}$ At first, non-scheds did business under a blanket exemption from certification requirements. ${ }^{25}$

17. The need for an efficient short-haul airplane to replace the DC-3 and other obsolete types now in operation is widely recognized. See Investigation of Local, Feeder, and Pick-up Air Service, 6 C.A.B. 1, 2 (1944). Air transport circles are seeking to establish a government sponsored research program for this purpose. The Air Transport Association, backing the proposal, claims use of present aircraft on short haul costs the airlines between $\$ 15$ and $\$ 20$ million more annually than estimated operating costs of planes still on the drawing board. Aviation Week, April 2, 1951, p. 48.

18. Cf. the tabulated "break-even needs" of feeders listed in Aviation Week, April 30,1951 , p. 52 .

19. It is "apparent that the provision of a short-haul and local service with aircraft will be, in a very great measure, an experimental operation, and constitutes a problem with respect to which we have little or no information of a factual nature. But since the experiment may well result in public benefit beyond present expectations, the responsibility imposed on us to encourage the development of an air transportation system justifies us, within reasonable bounds, in translating into results of experience what are now plans and estimates." Investigation of Local, Feeder, and Pick-up Air Service, 6 C.A.B. 1, 3 (1944).

20. Id. at 4. Cf. CAB, AnNuar Report 11 (1949).

21. The feeders' share of the domestic scheduled industry in 1950 was:

Assets 3\%

Number of Employees 8\%

Payroll 6\%

Scheduled revenue passenger miles $2 \%$

Number of passengers carried $6 \%$

Computed from statistics in Aviation Week, Feb. 26, 1951, p. 110. For conflicting arguments on the desirability of continued feeder operations, compare The Planned Promotion of Feeder Air Transportation, Address by Josh Lee, Member of the Civil Aeronautics Board, reprinted in 17 J. ATR L. 347 (1950), with Statement of Richard Hellman, Public Utility Economist. Hearings before Senate Committee on Interstate and Foreign Commerce on S. Res. 50, 81st Cong., 1st and 2d Sess. 2166, 2134 (1949).

22. See, e.g., In re Large Irregular Carrier Exemption, C.A.B. Serial No. E-4240-52, May 25, 1950, p. 6 et seq. (mimeo) ; Cf. Investigation of Nonscheduled Air Services, 6 C.A.B. 1049, 1052 et seq. (1946).

23. Fixed base operations refers to the activities at most local airports, including flight instruction, aircraft rental, sales and service, sight-seeing, and occasional cross-country charter flights. See ibid.

24. Ibid.

25. The Board may exempt any class of air carriers from the economic regulations. 52 Stat. 980, 1005 (1938), 49 U.S.C. $\$ 496$ (1946).

Pursuant to this authority the Board in 1938 adopted Section 292.1 of the Economic Regulations, 3 FED. REG. 2886 (1938), exempting non-scheds from certification requirements. Non-scheduled carriers were defined as: 
Because they flew none but profitable routes, usually waited for full passenger loads, and used only aircraft secured at a fraction of cost, they could beat trunk line established fares. ${ }^{26}$ Since the Board suspected heavy diversion of trunk line traffic, ${ }^{27}$ discovered examples of shoddy operation, ${ }^{28}$ and found flagrant disregard of the terms of their exemptions, ${ }^{29}$ it began to narrow the exemption in $1947 . .^{30} \mathrm{New}$ regulations require all non-scheduled carriers flying aircraft heavier than specified take-off weight ${ }^{31}$ to secure letters of registration containing severe restrictions on flight frequency. ${ }^{32}$ As a result, if this Board policy prevails, non-scheds may soon be defunct. ${ }^{33}$

"[T]he air carrier [who] does not hold out to the public by advertisement or otherwise that it will operate one or more airplanes between any designated points regularly or with a reasonable degree of regularity upon which airplane or airplanes it will accept for transportation, for compensation or hire, such members of the public as may apply therefor or such express or other property as the public may offer." Ibid.

For the whittling away of the exemption, see notes 30-3 infra and text. See Neal, The Status of Non-Scheduled Operations under the Civil Aeronantics Act of 1938, 11 LAw \& Contemp. Prob. 508 (1946) for general discussion of the legal status of non-scheds.

26. See testimony of former CAB Chairman Delos Rentzel before the Senate Small Business Committee investigating non-scheds' charges of $\mathrm{CAB}$ unfairness. Reported at Aviation Week, May 7, 1951, p. 65.

27. In re Large Irregular Carriers Exemption, CAB Serial No. E-4220-50, May 25, 1950, p. 16 (mimeo). Compare statistics in Aviation Week, Feb. 26, 1951, p. 110, with id., July 16, 1951, p. 72 , showing that in 1950 non-scheds flew revenue passenger mileage amounting to one-tenth of scheduled carriers' mileage. While scheds argue that up to one-third of non-scheds' passengers have been diverted from scheds, the non-scheds claim that their lower fares and reduced services are tapping entirely new demand strata. In re Large Irregular Carriers Exemption, supra, at p. 16.

28. "Disciminatory rates, misrepresentation and failure to furnish services contracted for, and the use of inadequate and makeshift equipment and facilities are some of the more flagrant practices which have become all too frequent. Indeed, in some respects the situation has become unhappily reminiscent of the state of affairs which gave rise to the passage of the Act." Id. at p. 9.

29. Most provided service with sufficient predictable regularity to lie outside the definition of non-scheduled services. See $i d$. at p. 19 ; note 23 supra.

30. Regulation Serial No. 388, May 5, 1947. 14 Code FEd. Regs. $\$ 292.1$ (1949). See notes 31-3 infra.

31. "If . . one allowable gross takeoff weight exceeds 10,000 pounds for any one unit or 25,000 pounds for the total of such units (disregarding units of 6,000 pounds or less), such carrier shall be classified as a 'Large Irregular Carrier'; otherwise, such carrier shall be classified as a 'Small Irregular Carrier'." 14 CODE FEd. REGS. \$292.1 (1) (1949). "Small Irregular Carriers" (designed under the weight differentiation described above to include fixed base type operations) are exempted from the letter of registration requirements. 14 CODE FED. REGS. $\$ 292.1$ (2) (c) (2) (1949).

32. Generally, the "irregulars" are limited to three round trips a month between any pair of large cities.

For a detailed definition, with numerous examples, of "irregular," the successor of "non-scheduled" see long note, 14 CODE FED. REGS. 517 (1949).

33. There is some indication that the CAB may be backtracking slightly from its stringent restrictions which could destroy the non-scheds. The three trips a month rule 
Among the trunk lines, increasing competition was encouraged by the Board until recently. ${ }^{34}$ The Act itself calls for "competition to the extent necessary to assure the sound development of an air transportation system. ..."35 Since, unlike railroad or public utility operation, airline competition need not involve wasteful duplication of costly facilities, ${ }^{36}$ Congress wished to maintain competitive incentives. ${ }^{37}$ Accordingly, the Board granted applications of the individual trunk lines to extend their routes in competition with other trunks unless clearly not justified by traffic potential. ${ }^{38}$

This policy of gradually extending competition could have given the route pattern the flexibility appropriate to a fast-growing industry..$^{39}$ But a significant departure from this policy has occurred. Denying the applications of

has been slightly modified to permit eight round trips a month between New York-Puerto Rico and Miami-Puerto Rico. The restrictions are temporarily removed for military contract flights. Aviation Week, March 19, 1951, p. 64. It is at least doubtful whether these modifications will allow any of the non-scheds to stay in business long.

For vigorous criticism of the CAB's restrictions on non-scheds, see report of the Senate Small Business Committee discussed at Aviation Week, July 16, 1951, p. 72.

The three trips a month order has been permanently enjoined because the $C A B$ did not grant individual hearings to affected carriers before effectuating its order. American Air Transport, Inc. v. CAB, 98 F. Supp. 660 (D.D.C. 1951).

34. For an expression of the CAB's policy of competition among established carriers, see note 38 infra. The percentage of the total airline passenger revenue subject to "effective competition" increased from $41 \%$ to $59 \%$ between 1940 and 1947. GiLL \& Bates, Arruine Competirion 24 (1949). For description of the recent shift in CAB attitude toward competition, see Coast to Coast by Interchange, Business Week, April 7, 1951, p. 68. See also discussion at pp. 1210-11 infra.

35. 52 SтAт. 980 (1938), 49 U.S.C. $\$ 402$ (1946).

36. Since the airlines generally do not build airports and pay only token charges for their use, there are no expenses in opening a new route even remotely comparable to laying railroad tracks or stringing power lines. See Hearings, supra note 21, at 2119.

37. The CAB accepted the Congressional position: "It is of the greatest importance ... to maintain a properly balanced system of air transportation in every section of the country in order to encourage constructive competition. That healthy competition is presumed to be beneficial to the public may be inferred from various Congressional expressions." Braniff Airways, Inc., 2 C.A.B. 353, 386 (1940).

38. The Board has utilized the "presumption doctrine" during the late war and early post-war years to favor competition. The North-South California Service case summarizes the doctrine:

"II]t would seem to be a sound principle that, since competition in itself presents an incentive to improved service and technological development, there would be a strong, although not conclusive, presumption in favor of competition on any route which offered sufficient traffic to support competing services without unreasonable increase of total operating cost." Transcontinental \& Western Air, Inc. et al., Additional North-South California Services, 4 C.A.B. 373, 375 (1943).

39. Furthermore, some of the larger and more responsible non-scheds might have been certificated into route operations to soften the blow of the current "death edict" directed at them, discussed at note 33 supra. 
several airlines for a through-route from Florida to the Pacific, ${ }^{40}$ the Board instead proposed to satisfy traffic demands for through-service ${ }^{41}$ with equipment interchanges. ${ }^{42}$ Under these arrangements, one airplane makes the entire flight, but is operated by the participating airlines as it crosses their systems. ${ }^{43}$ Warning that it would disapprove any interchange likely to divert traffic from any carrier, ${ }^{44}$ the Board in effect announced a freeze of the domestic route pattern.

\section{Financial Assistance}

Federal financial aid flows to the airlines in two forms. One, an indirect subsidy, is free use of the Federal Airways System for navigation information and in-flight traffic control. ${ }^{45}$ The other is a direct operating subsidy in the form of mail pay authorized under the Civil Aeronautics Act. ${ }^{40}$

The airlines are not favored specially in their receipt of an indirect subsidy. From early days, transportation systems have been assisted in this way. ${ }^{47}$ And, though transportation needs may justify the subsidy principle, ${ }^{48}$ its administration in the airline industry is wide open to attack.

40. Southern Service to the West Case, C.A.B. Serial No. E.5090, Jan. 30, 1951 (mimeo).

41. Through-service is provided when one airplane makes the entire trip, as opposed to connecting-service which requires through-passengers to change carriers and/or planes.

42. Southern Service to the West Case, C.A.B. Serial No. E-5090, Jan. 30, 1951, p. 32 (mimeo).

43. Interchange agreements normally provide for flight and ground crews of the participating airlines to operate the equipment over their own systems. Major maintenance, on the other hand, is handled exclusively by the owning airline. Revenues allocable to each segment of the interchange flight are divided according to the ratio of costs which the participating lines agree to assume. See, e.g., Joint Application of Braniff Airways and American Airlines With Respect to Interchange, C.A.B. Dkt. No. 4666, filed Sept. 15, 1950.

44. "It would appear to be fundamental that the interchanges which would best satisfy the public interest would be those which would cause the minimum interference with the existing route pattern. . . . [T] $]$ he interchange arrangement which would be most consistent with the public interest would be one which would leave substantially undisturbed the historical participation of the various existing carriers in the traffic movement to be served, and which would not cause undue diversion." Southern Service to the West Case, C.A.B. Serial No. E-5090, Jan. 30, 1951, pp. $32-3$ (mimeo).

45. See Behling, Subsidies to Transportation, U.S. Legrszative Reference Service Public Affairs Bulletin No. 8630 et seq. (1950).

46. 52 Stat. 973, 998-1000 (1938). 49 U.S.C. $\$ 486$ (1946). For general discussion of the direct subsidy, see Behling, supra note 45 , at 30 et seq.

47. Transportation has always been considered a proper subject of indirect governmental assistance. Waterways, highways, and land grants have long aided carriers. See e.g., Behling, supra note 45, at 17-29. Governmental expenditure in these areas has been estimated at $\$ 750,000,000$ for airways and airports, $\$ 1,443,000,000$ for railroads, $\$ 3,314,-$ 469,305 for rivers and harbors, and $\$ 56,011,000.000$ for highways. Civil Aeronautics Administration, Economic Aspects of America's AIr Navigation Program, reprinted in Hearings, supra note 21, at 1955-7.

49. "We consider that direct Government financial aid to commercial air lines is fully justified on grounds of national security and economic welfare." REPORT of the PREsIdent's Am Policy Comimission, Survival in the Air Age 102 (1948). 
Need rather than performance has been the key to subsidy receipts. The Post Office Department pays the individual airlines on the basis of $\mathrm{CAB}$ formulae. ${ }^{49}$ The actual techniques for computing subsidy formulae vary, since the Act gives the Board authority to use virtually any device it wishes. ${ }^{50}$ At present, some carriers are paid set or sliding rates based on ton-miles of mail carried. Others are paid a set rate per plane-mile flown, regardless of the amount of mail carried. All may receive retroactive payments should actual conditions deviate from the forecast on which the original rates were established. ${ }^{51}$ In effect, the airlines hold a permanent cost-plus contract with the government. ${ }^{52}$

\section{The INDUSTRy TODAy}

\section{Industry Structure}

Enormous size discrepancies exist within the airline industry. Four airlines, giants by comparison, dominate the picture and generate $70 \%$ of domestic passenger miles. ${ }^{53}$ American, United, and Trans-World Airlines segmentize the east-west transcontinental market with roughly parallel routes. All three lines serve Chicago. Eastern Airlines blankets the area east of the Mississippi. American, United, and TWA all compete in the transcontinental market as well as on the important New York-Chicago and WashingtonChicago runs. Eastern, on the other hand, meets no important big four competition in its major markets. ${ }^{54}$

49. Under this form of payment the amount paid as actual compensation for carrying the mail is uncertain. The accounting practices of the airlines do not indicate what part of their costs are properly allocable to carrying the mail and neither the CAB nor the Post Office Department attempted such a separation in the past. It has been estimated that of the $\$ 58$ million domestic mail payments in 1949 only $\$ 20$ million represented reasonable compensation for carrying the mail. The remainder is an annually recurring subsidy to the carriers. Separation of Air-Mail Pay from Subsidy-Interin Report of Senator Edwin C. Johnson, Chairman of the Committee on Interstate and Foreign Commerce, on May 5, 1950, reprinted at 17 J. AIR L. 333 (1950). Total air mail payments to the domestic lines in the fiscal year 1950 amounted to $\$ 60.9$ million. Aviation Week, April 2, 1951, p. 45. A move is now under way in Congress to require a separation of subsidy from compensation in these payments. A bill to this effect has been introduced in the Senate, S. 1657, 82d Cong., 1st Sess. (1951), by Sen. Edwin C. Johnson. It provides fixed mail payments for different classes of carriers. Aside from such payments, the $\mathrm{CAB}$ could still grant subsidies based on individual carrier need.

50. The Board "is empowered ... to prescribe the method or methods, by aircraftmile, pound-mile, weight, space, or any combination thereof, or otherwise, for ascertaining" mail rates. 52 STAT. 973, 998 (1938), 49 U.S.C. \$ 486 (1946).

51. For general discussion, see Aviation Week, June 4, 1951, pp. 59 et seq.

52. In exercising this important authority, the CAB's statutory guide directs that a rate be paid each carrier which will enable it "under honest, efficient and economical management to maintain and continue the development of air transportation" in the public interest. 52 StaT. 973, 998 (1938), 49 U.S.C. \$ 486 (1946).

53. See graphs at pp. 1205-6 infra.

54. See route charts at pp. 1203-4 infra. 


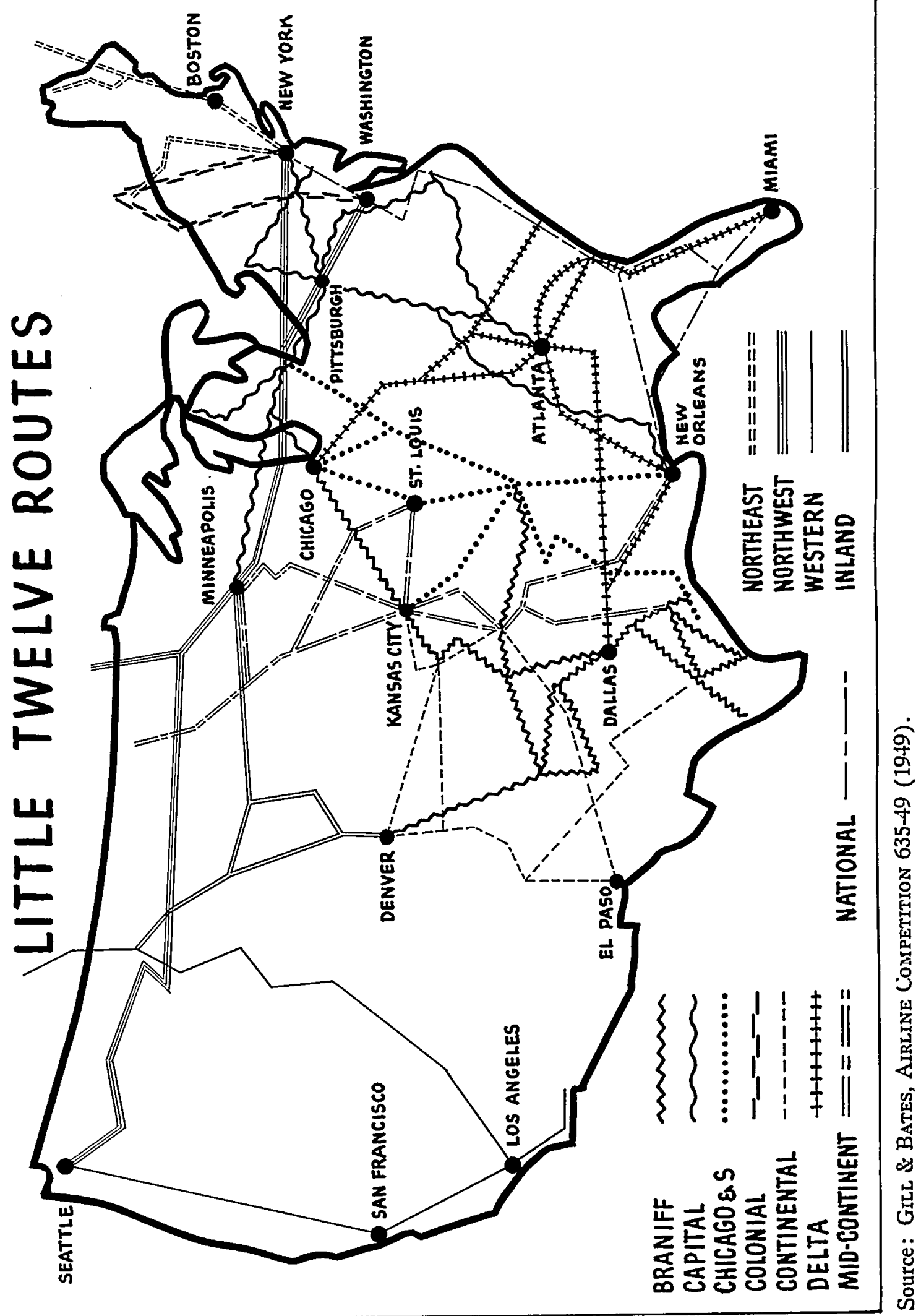




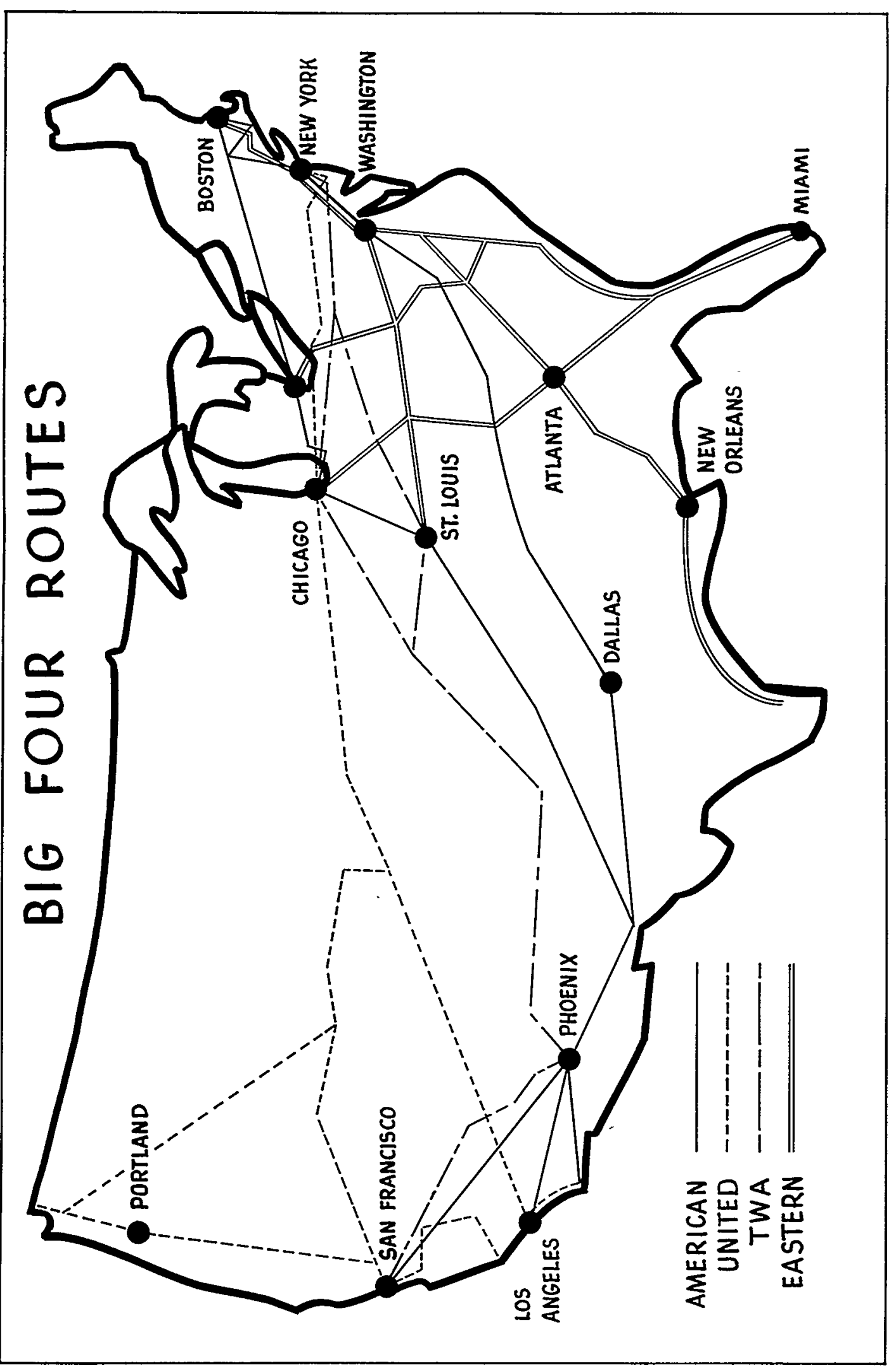


1. SHARES OF TOTAL REVENUE PASSENGER MILES*

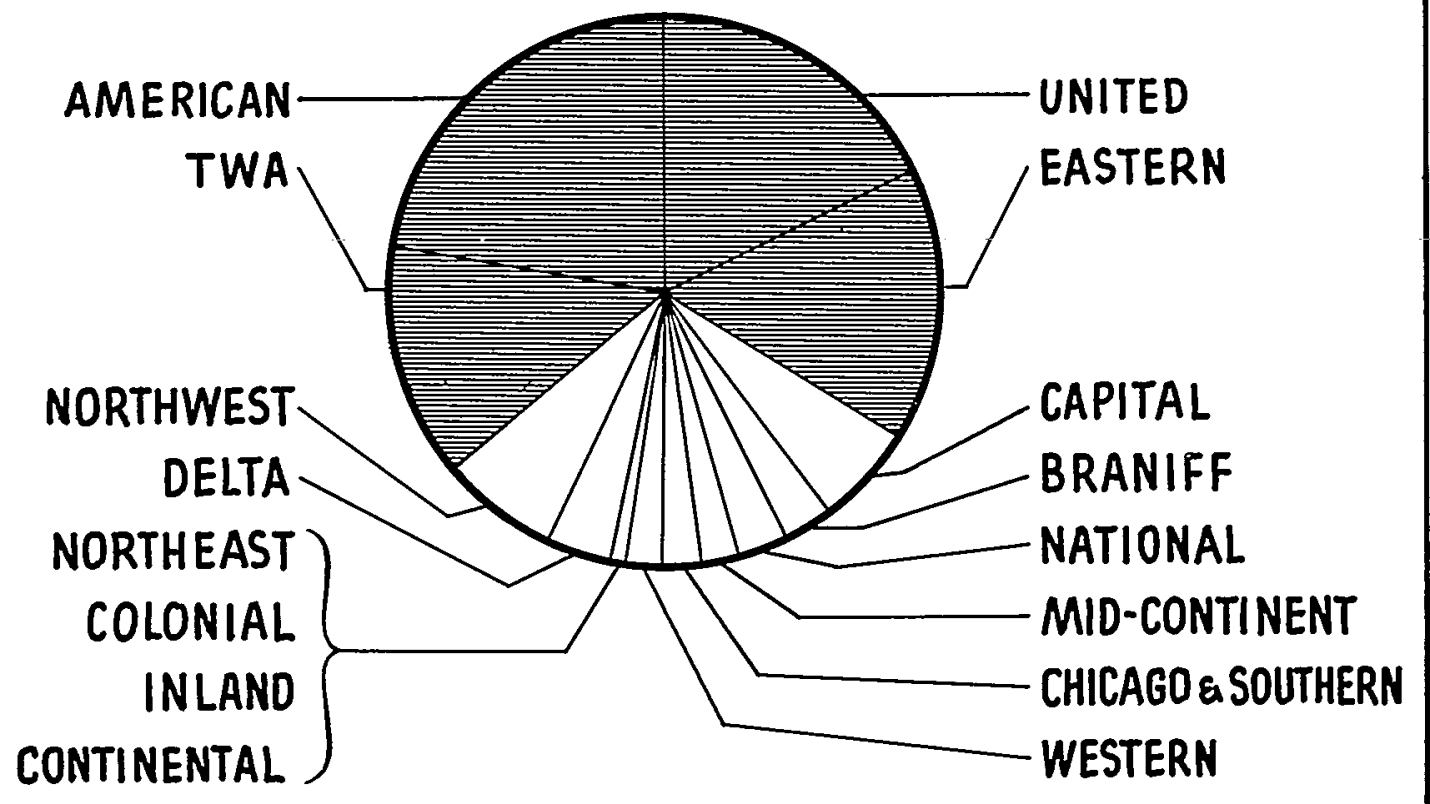

*Computed from statistics at Aviation Week, Feb. 26, 1951, p. 110.

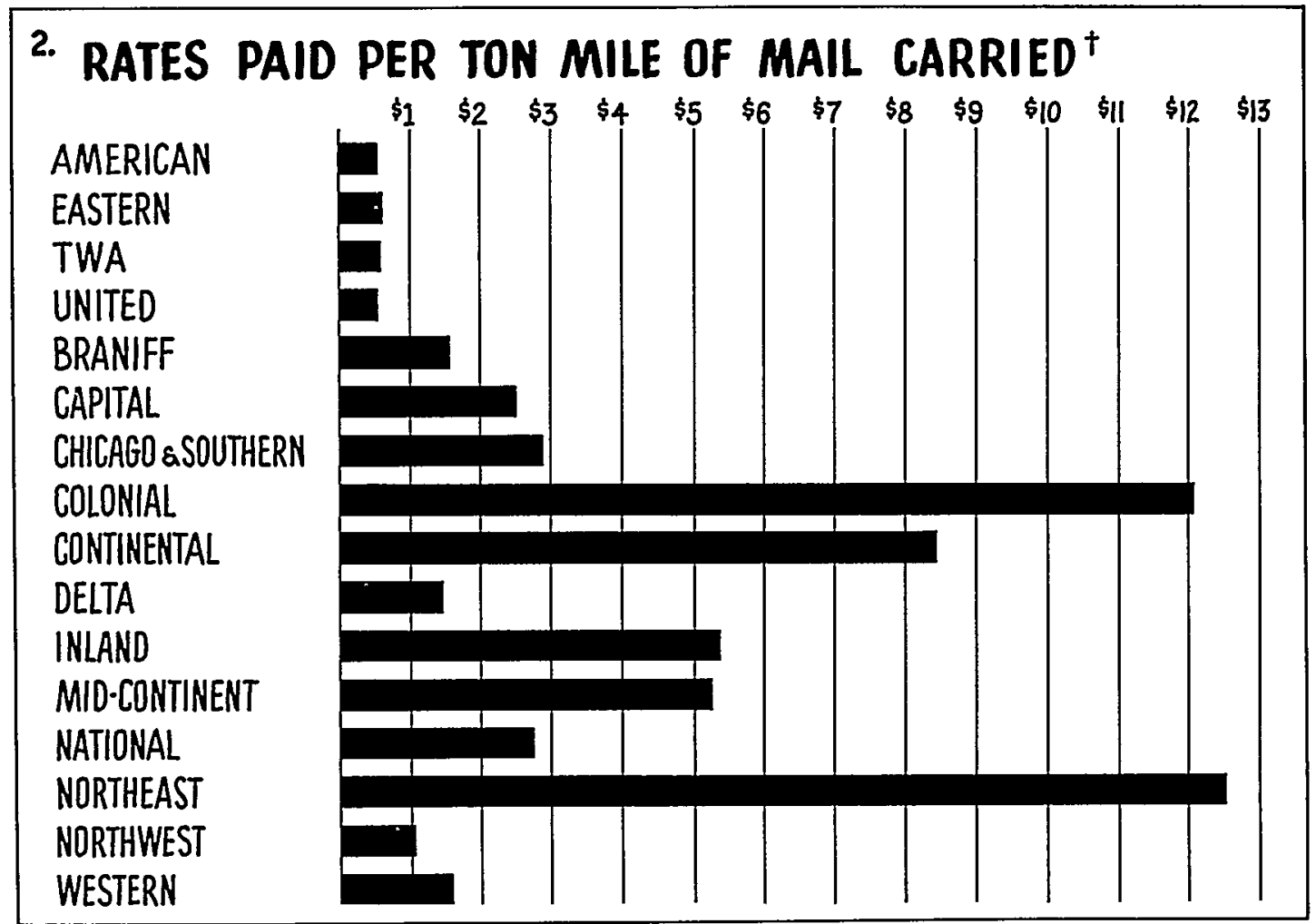

† Source: Aviation Week, June 4, 1951, p. 59. 


\section{UNSUBSIDIZED PROFIT or LOSS PER AIRCRAFT MILE**}

PROFIT IN CENTS

AMERICAN

EASTERN

TWA

UNITED

BRANIFF

CAPITAL

CHICAGO\&SOUTHERN

COLONIAL

CONTINENTAL

DELTA

INLAND

MID-CONTINENT

NATIONAL

NORTHEAST

NORTHWEST

WESTERN

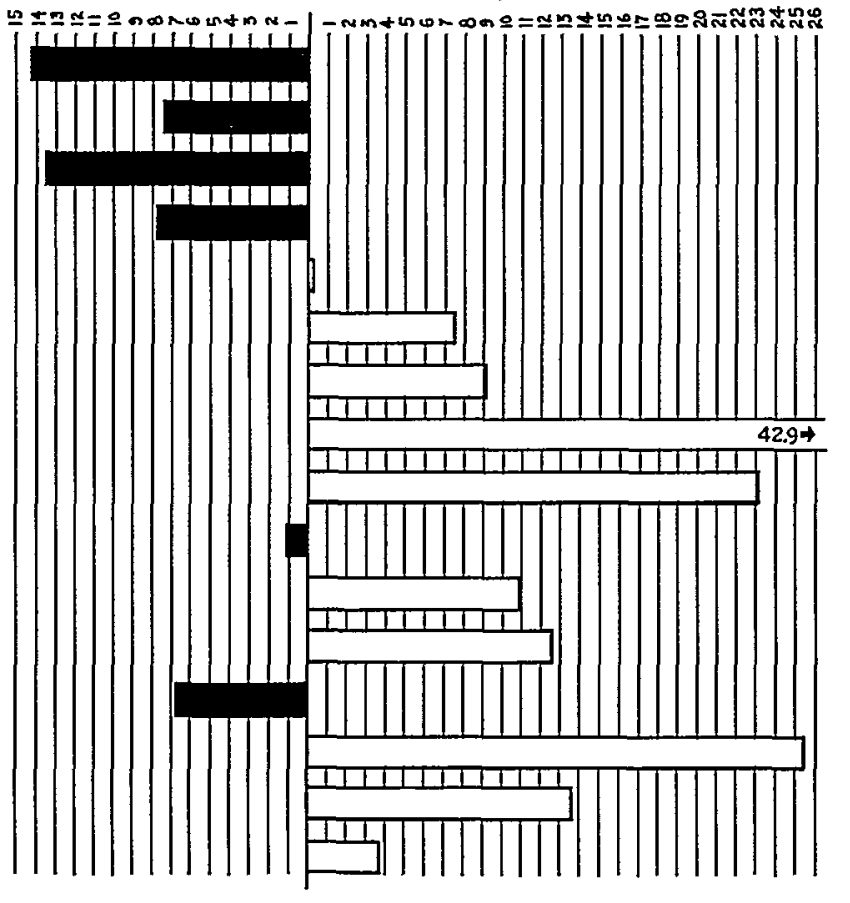

**Computed by applying the compensatory rates for mail carriage established in the Senate mail pay/subsidy separation bill (note 49 supra) to operating statistics contained in AIR TRANSPORTATION Ass'N OF AMERICA, Airline Operating Statistics (1950).

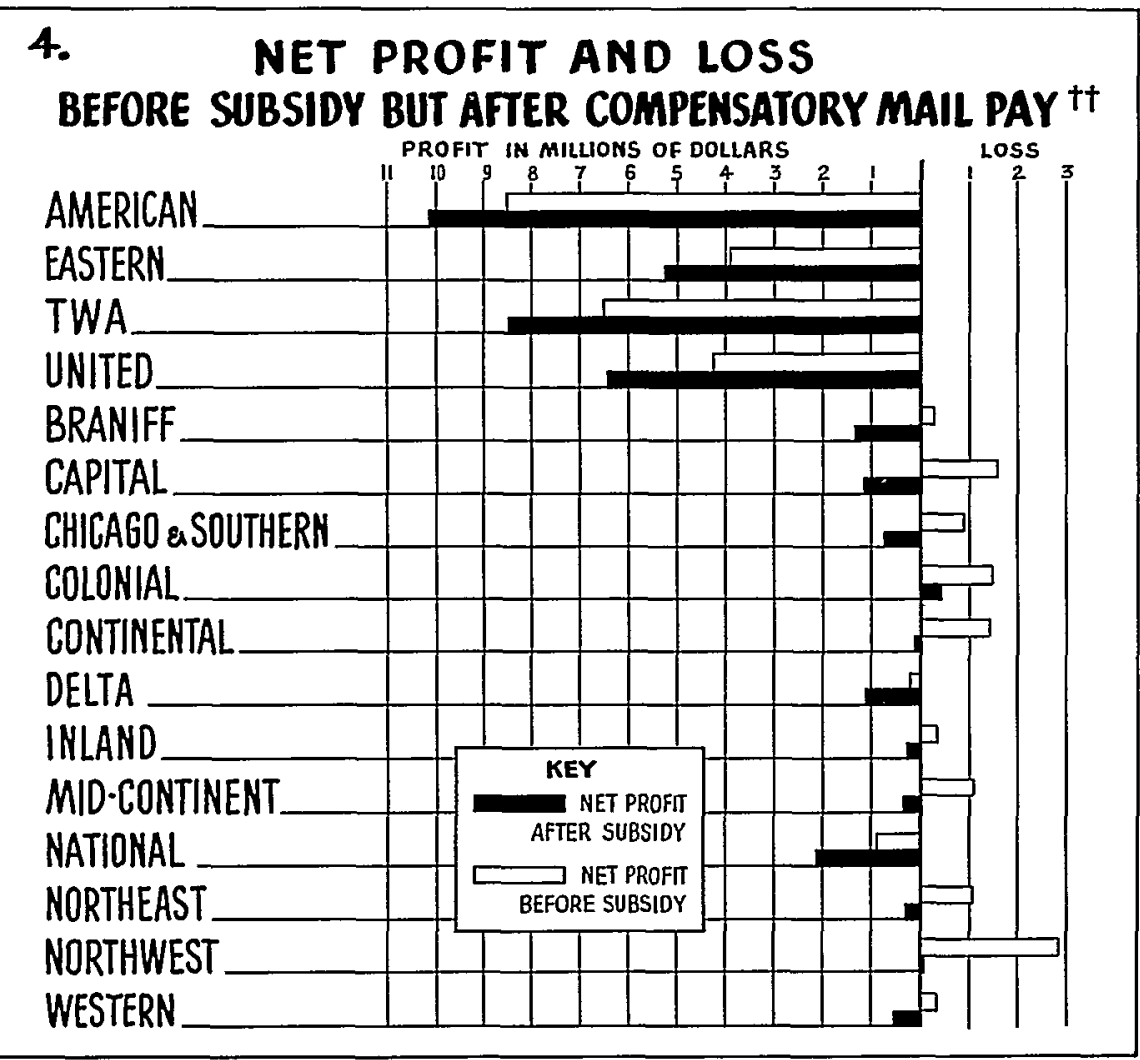

tf Computed by applying the compensatory rates for mail carriage established in the Senate mail pay/subsidy separation bill (note 49 supra) to operating statistics contained in AIR TransPortation Ass'N OF AMERICA, 
The big four, individually and collectively, lead the industry in profitability. Furthermore, they are now operating without benefit of any mail subsidy. ${ }^{50}$ The remaining carriers-the little twelve-earn less and are directly subsidized in differing degrees. ${ }^{57}$

\section{Little Truelve Problems}

Within the industry, cost per mile flown has no definite relation to individual firm size. In the past, some small lines have equalled or bettered the unit cost performance of the Big Four. ${ }^{58}$ Thus inability to compete effectively with the Big Four, rather than cost disadvantages of small scale operations, is responsible for the high subsidy needs of the Little Twelve. ${ }^{\pi 9}$

Scheduling is one major competitive handicap of the smaller lines. An airline's flight schedule in a given market represents a large part of its service. Frequent departures at convenient hours are the ideal. A large carrier with

55. This refers to unsubsidized profitability. See graphs at pp. 1205-6 supra.

56. Because inadequacies in airline accounting procedures preclude segregation of the industry's costs allocable to mail services, a carrier's profitability aside from subsidy receipts cannot be determined. See note 49 stipra. The pending "subsidy separation bill," ibid., on the basis of research studies sets up purely compensatory airmail payment figures. Since only the Big Four now receive mail payments not in excess of the proposed compensatory criteria, they are the sole non-subsidized carriers according to these standards. For present Big Four receipt statistics, see Aviation Week, June 4, 1951, p. 59.

57. Compare graphs at pp. 1205-6 supra.

58. Total operating expenses per revenue ton mile for the individual carriers during the years 1943 and 1948 were:

\begin{tabular}{|c|c|c|}
\hline & $\begin{array}{c}1943 \\
\text { Cents }\end{array}$ & $\begin{array}{l}1948 \\
\text { Cents }\end{array}$ \\
\hline$\ldots \ldots, \ldots, \ldots, \ldots$ & 85 & 54 \\
\hline$\ldots \ldots, \cdots, \cdots, \cdots, \cdots$ & 80 & 54 \\
\hline 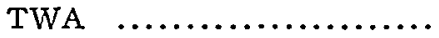 & 94 & 57 \\
\hline UNITED $\quad \ldots \ldots \ldots \ldots \ldots \ldots \ldots$ & 91 & 55 \\
\hline Braniff $\quad \ldots . ., \ldots \ldots$ & 83 & 59 \\
\hline$C \& S, \ldots \ldots \ldots, \ldots \ldots \ldots, \ldots$ & 101 & 66 \\
\hline Capital $\quad \ldots \ldots \ldots \ldots \ldots \ldots \ldots$ & 111 & 64 \\
\hline Colonial $\quad \ldots \ldots \ldots \ldots \ldots, \ldots, \ldots$ & 111 & 86 \\
\hline Continental $\ldots \ldots \ldots \ldots \ldots \ldots$ & 78 & 73 \\
\hline Delta $\ldots \ldots \ldots \ldots \ldots \ldots \ldots \ldots$ & 93 & 64 \\
\hline Inland $\quad \ldots \ldots, \ldots, \ldots, \ldots, \ldots$ & $59^{\circ}$ & 74 \\
\hline Mrid-Continent $\ldots \ldots \ldots \ldots \ldots \ldots$ & 63 & 69 \\
\hline National $\ldots . . . . . .$. & 73 & $\$ 2$ \\
\hline Northeast $\ldots \ldots \ldots \ldots \ldots \ldots \ldots$ & 121 & 100 \\
\hline Northwest $\ldots \ldots \ldots \ldots \ldots \ldots \ldots$ & 94 & 68 \\
\hline Western $\quad, \ldots \ldots \ldots \ldots \ldots \ldots \ldots$ & 95 & 70 \\
\hline Average all carriers $\ldots . . . \ldots \ldots$ & 88 & 58 \\
\hline
\end{tabular}

Source: CAB, Annual Airdine Statistics 21-8 (1943); id. at 42-6 (1948).

59. Three of the Little Twelve, however, encounter no Big Four competition. See Route Charts, at pp. 1203-4 supra. Lean rottes account for the subsidy dependence of Inland, Continental, and Mid-Continent. 
an ample fleet is in a position to saturate a given market with schedule service. Consequently, it can supply peak demand and shift its aircraft to other markets during slack periods. But smaller companies may be competitively pinched. Northeast, for example, has felt this disadvantage in competition with American on the dense New York-Boston run. ${ }^{60}$ Both carriers provide equal facilities and service except for scheduling. Northeast's fleet of only five Convairs, ${ }^{01}$ at best can schedule hourly departures from each terminal and still cover the rest of its system with a minimum of service. ${ }^{62}$ American, ${ }^{63}$ on the other hand, can schedule heavily in the early morning and evening to tap the bulk of the commuter-type traffic. At other hours, these American aircraft can be deployed to other runs. Moreover, whenever Northeast begins to make traffic inroads, American can temporarily step up its service on this run to regain its lost traffic from Northeast. ${ }^{64}$

The large carriers' through-routes confer important advantages. In dense, competitive markets, many passengers travel to or from cities outside those market areas. ${ }^{65}$ Other things equal, passengers distinctly prefer throughplanes, or at least single-carrier service. ${ }^{66}$ Consequently, the larger carrier with routes extending well beyond the dense market area may command most of the through-passengers. Resulting greater traffic volume supports more flights

60. Cf. Communication to the Yale Law Journal from C. W. Kriete, Director of Economic Research, Northeast Airlines, dated June 27, 1951, in Yale Law Library: "Northeast increased its appropriation for advertising promoting the New York-Boston non-stop service. . . . As an example of [this program's] success the number of New York-Boston passengers carried by us during the sample months of November, December, January, and February rose from 23,995 to 41,479 . . . However, American has recently added 7 round trips a day to its New York-Boston schedule and the effect of this on our participation in this traffic remains to be seen."

61. Aviation Week, Feb. 26, 1951, p. 110. Northeast also owns DC-3's, which, however, cannot match Convair service and thus are not flown on the competitive New YorkBoston run. Ibid.

62. Since each round trip between New York and Boston requires three hours, servicing time included, three planes are needed to provide hourly departures from each terminal. Therefore, where one plane is held in reserve, only one other is available for Convair service to the remainder of the system.

63. American's system includes 79 Convairs and 49 DC-6's, competitively equivalent to the Convair for short and medium hauls. Ibid.

64. Cf. note 60 supra. In June 1951, American added 7 flights on the New YorkBoston run, resulting in a daily schedule of 56 flights in each direction. Northeast, on the other hand, operated only 12 such flights daily. Offictal Atruine Guide (June 1951).

Competitive overscheduling is hard to control. Proof is difficult. Moreover, large carriers are in a better position to overschedule, and their relative independence of mail subsidy precludes one effective $\mathrm{CAB}$ sanction. Hearings, supra note 21 , at 2126 .

65. For example, in March 1949, 35\% of passengers boarding the Boston-New York run were traveling beyond New York. In the same month, $75 \%$ of the passengers boarding New York-Chicago traveled beyond Chicago. Computed from statistics in $2 \mathrm{CAB}$, Amline Traffic Survey (March 1949), and Gotce \& Crawford, Atruine Station ANalyses, (1st Quarter 1949).

66. See note 41 supra. 
on this particular competitive segment and compounds the advantage of the large carrier, who thus can offer more frequent service to local passengers.

Ability to meet seasonal fluctuations of traffic demand is a further asset. At least two small carriers, National and Northeast, experience serious seasonal traffic fluctuations. ${ }^{67}$ Even on non-competitive seasonal routes, such as Northeast's Cape Cod and Maine segments, this is a serious handicap. In the competitive New York-Florida market, ${ }^{\text {bs }}$ the disadvantage is even more acute. There, National competes with Eastern, one of the Big Four, whose seasonal fluctuation represents only a minor percentage of its total seat-miles because of extensive routes elsewhere. ${ }^{60}$ Obviously, a sufficient number of aircraft to fully exploit peak demand periods cannot be economically supported all year. Thus the combination of seasonal routes and small size forces some of the Little Twelve to turn away business during peak periods.

Moreover, there is the intangible but undoubtedly potent advantage held by the Big Four merely because they are more widely known. Although a comparative carrier safety analysis shows scheduled airlines to be safer than trains or cars, ${ }^{70}$ air crashes are still headline news and cut into sales. And air travelers may feel that flying on a known line is safer. Sheer size, of course, is important to how well an airline is known. Furthermore, the Big Four have spent millions on large scale national advertising that smaller lines do not match. ${ }^{71}$

These advantages not only help make the Big Four profitable but create more favorable financing terms. Big Four stock is more marketable and their bonds are floated at interest rates lower than the Little Twelve can get. ${ }^{72}$ The greater capital required to purchase modern aircraft sharpens the smaller carrier's disadvantage. ${ }^{73}$ Furthermore, modern aircraft's stepped-up speed and capacity tend to whittle the number of planes in a fleet. And sound

67. Regarding the difference between low and high months as a fraction of the high month totals, the industry seasonality percentage in 1949 was 28 per cent. National's and Northeast's percentages were 45 and 54 per cent. Computed from AIR TRANSPORT Ass'n of America, Airline Operating Statistics (1949).

68. See route charts pp. 1203-4 supra.

69. Eastern's seasonal fluctuation, cf. note 67 supra, was only 17 per cent. For analysis of Eastern's competitive advantage over National, see Grul \& BATEs, AIRLINE Conipetition 286 (1949).

70. See statistical study, Aviation Week, Feb. 5, 1951, p. 17. Passenger fatalities, however, are proportionally higher for air travel. Ibid.

71. 1950 advertising expenditures ranged from $\$ 23 / 4$ million by American to $\$ 96$ thousand by Inland. Arr Transport Association of Amrerica-Arrline Finance and Accounting Conference, Comparative Statistics of Air Carrier Incone and Expenses. 12 Months Ending Dec. 31, 1951.

72. See CaB, Comparative Costs of Air Carrier Capital 74 (Revised Dec. 31, 1947).

73. Capital cost per available seat mile rose $116 \%$ from 1943 to 1948 . Computed from statistics contained in CAB, Annual Amrine Statistics 20, 33 (1943); id. at 17, 58 (1948). 
operating practice that requires a carrier to keep at least one aircraft of each type in reserve can cause troublesome utilization problems for the smaller airline. When it owns, for example, only three Constellations, as does Chicago and Southern, ${ }^{74}$ a third of a three million dollar investment may be idle.

\section{Possible Avenues of Improvement}

\section{Current $C A B$ Approach}

The CAB has indicated awareness of these problems and has on occasion stressed the need for strengthening the smaller lines. ${ }^{75}$ This need plus a stronger preference for competition than now exists ${ }^{76}$ led the Board in the past to certificate many small lines into more profitable markets. ${ }^{77}$ But most of these profitable markets were already served by at least one of the Big Four. Because of the competitive weaknesses of the small lines, the extensions were, at best, a halfway measure. And the Board's willingness to entertain applications for voluntary mergers ${ }^{78}$ has produced little constructive response from the lines. ${ }^{79}$

In a recent policy pronouncement, ${ }^{80}$ the Board not only glossed over the need for strengthening the smaller lines, but apparently froze the existing unbalanced route structure. Even if the small lines participate in the equipment interchanges suggested by the $\mathrm{CAB}$, all former shares in the traffic are to be preserved. ${ }^{81}$ Accordingly, no interchange will be approved which gives any line a greater share of the total traffic generated previously by consolidated schedules. $^{82}$ That the $C A B$ has borrowed a railroad term in discussing an acceptable type of interchange agreement points up the weakness of this policy.

74. Aviation Week, Feb. 26, 1951, p. 110.

75. See, e.g., CAB Release 51-65, Sept. 14, 1951.

76. See notes 32 and 36 supra.

77. See, e.g., Northeast Airlines, Additional Service to Boston, 4 C.A.B. 686, 690, 695 (1944). See also notes 36 and 37 supra.

78. See e.g. CAB Release 51-65, Sept. 14, 1951 and Hearings, supra, note 21, at 1143.

79. Only one merger application is currently pending before the CAB. New EnglandSouthern States Merger Investigation, CAB Release 51-65, Sept. 14, 1951. A merger of Northeast and Delta is proposed. From the point of view of the industry as a whole this proposal has two major weaknesses. Operationally it creates two divisible systems, one in New England and one in the South, connected only by a new route from Atlanta to New York. Except for some balancing of seasonality, it does little to strengthen either line operationally. Approval of this new route, on which the merger is contingent, would increase to three the competitors serving the New York-Atlanta run.

The current subsidy program does nothing to encourage mergers because it compensates for operating deficits. In the absence of compelling pressure, management cannot be expected to favor dislocations involved in mergers or consolidations. See Altschul, Airlinc Merger Reports Increase, Aviation Week, July 23, 1951, p. 18.

S0. Southern Service to the West Case, C.A.B. Serial No. E-5090, Jan. 30, 1951 (mimeo).

81. See note 42 supra.

S2. Ibid. 
When a member is unable to contribute equipment to the interchange, he still gets a slice of the revenue in return for "trackage rights." 83 This simply means that an airline which happens to hold a route certificate for a given area can extract a toll for the right to serve some market within its territoryeven though it itself provides no services. ${ }^{84}$ Unlike railroads, airlines have no heavy capital investment in their routes to justify trackage charges. ${ }^{85}$ Neither the Act nor good sense calls for valuation of an airline's right to fly from here to there. The CAB policy, in short, contributes nothing toward the industry's basic need-a route structure which affords equal competitive opportunities to all carriers.

\section{Competition}

Unregulated competition might provide the dynamism lacking in the CAB's approach. ${ }^{86}$ Advocates of competition justify earlier economic regulation as needed assistance to a struggling infant industry. Now that the industry no longer needs encouragement and a major part of it no longer depends on direct subsidy, the argument runs, all economic controls over routes, entry and fares should go. The subsidy would be abolished. Competition, antitrust and safety laws would police the industry.

But as long as public policy demands air service to uneconomic areas, competition cannot free the industry from economic control. Some coercion or stimulus must be used if such service is to be provided. Under current regulatory practice, route control and subsidization in effect condition the privilege of developing profitable routes on serving lean markets. Were airlines under no restraints and free to fly wherever they chose, either a government owned airline or a special subsidy would have to fill the gap.

A government-owned airline system to supplement a competitive industry is not only politically distasteful, but would be operationally impracticable as well. The need for hinterland air service is not restricted to any particular geographic area. Rather, smaller towns which need air service out of proportion to their ability to support it are scattered throughout the country. But they are generally along or near some self-supporting air route. Serving them in conjunction with that route is clearly a more efficient technique than establishing a separate new organization.

Special subsidies for service to each uneconomic area or city seem equally unworkable. The accounting problems involved in fixing a fair cost for such

83. Southern Service to the West Case, C.A.B. Serial No. E-5090, Jan. 30, 1951 p. 46 (mimeo).

84. The concept of "trackage" is an objectionable extension of an earlier Board decision that in acquisition cases a value may properly be placed on the certificate of the purchased airline. See Acquisition of Marquette by TWA (Supplemental Opinion), 2 C.A.B. 409 (1940). See Notes, 61 Harv. L. Rev. 523 (1948), 48 Col. L. Rev. 88 (1948).

85. See note 36 supra.

86. For a strong statement of this position, see Hearings, supra note 21 , at 2137 et seq. 
service are in themselves formidable. ${ }^{87}$ But preventing the extraction of exorbitant subsidies from the government for the services rendered is a more fundamental difficulty. The nature of air transportation ensures that only a limited number of lines can be in a geographic position to integrate efficiently a given city or area into their systems. Since under these conditions effective competitive bidding would be improbable, a carrier might be able to name its own price. If, on the other hand, some line is made to provide that service at a government-fixed price, the industry is no longer freely competitive. Either alternative, government ownership or the special subsidy, seems a cumbersome means compared to existing methods.

Aside from problems of serving uneconomic areas, abandonment of economic controls might be dangerous in any event. Antitrust problems could plague a "liberated" airline industry. Carriers nurtured on co-operative setting of fares ${ }^{8 s}$ are not likely to begin competing tooth and claw without assurance that rate reductions would bring large increases in total revenues. ${ }^{80}$ Informal agreements to fix fares and divide routes might stifle competition before it got started. Because the firms in the industry are few and even fewer lines serve any one route, collusive agreements are a simple matter.90 Under the same conditions, parallel pricing, even without overt agreements is likely. ${ }^{11}$ Moreover, high capital requirements may block the entry of additional competitors. Financing a system comparable to the Big Four would call for heavy aggregations of capital. ${ }^{92}$ And a small company attempting to break into the field to compete with large established firms would encounter

87. Airline accounting techniques do not enable an allocation of costs to particular operations. Hearings, supra note 21 , at 2040-1. Thus, establishing a fair subsidy for service to a particular city or route would have to proceed without concrete cost standards.

88. See, e.g., CAB ANnual Report 31 (1949), describing a CAB-sponsored meeting of airline presidents for the purpose of discussing the level of airline fares. These meetings are informal and their results technically have no binding effect. But since the $\mathrm{CAB}$ sponsors the meetings, attempts of individuals to file non-conforming tariffs might result in $\mathrm{CAB}$ disapproval.

89. No such assurance now exists. At existing fare levels the airlines are steadily attracting passengers from Pullman travel. Aviation Week, April 16, 1951, p. 65. It is probable that safety fears rather than price considerations primarily deter present Pullman travelers from air travel. Cf. Hearings, supra note 21, at 1696. Rail coach is the next important strata of transportation demand to which airlines can aspire. Id. at 2129-30. But attempts to tap this mass market are unlikely in the near future since the lines are operating close to capacity with existing equipment. Aviation Week, April 16, 1951. p. 65. In view of the distant and uncertain delivery dates now being quoted by aircraft manufacturers it is unlikely that any extensive experimentation with demand elasticity will occur in the next few years unless a period of industry adversity recurs.

90. For analysis of the collusive tendency of markets with few firms, see Fell NER, Competition Among the Few (1950) passim; Bain, Pricing, Distribution and EMPLOYMENT 176-221 (1948).

91. Ibid.

92. Three of the Big Four had assets exceeding $\$ 100$ million in 1950. Aviation Week, Feb. 26, 1951, p. 110. 
the same handicaps frustrating the small firms today. ${ }^{93}$ In sum, structural conditions in the industry are not conducive to functioning free competition.

Moreover, reduction of firm size to ease entry and facilitate competition might impair operational efficiency. An airline big enough to serve the transcontinental markets is probably big enough to present a capital problem to prospective competitors. ${ }^{94}$ But reduction of airline size below this level may chop up natural non-stop runs and necessitate the cumbersome expedient of equipment interchanges. ${ }^{95}$ Restructuring the industry to set up one non-stop and several local-service companies for serving the same route would keep firm size down. But such a program offers no added competitive benefits. Local-service carriers would not compete with the non-stop carrier nor with each other, since few local routes would support more than a single carrier. Furthermore, today's aircraft make long hauls more profitable than short. ${ }^{90}$ Accordingly, atomization into long and short-haul carriers necessarily favors the company serving the long-haul market.

Finally, unlimited competition may revive industry instability. The Civil Aeronautics Act not only aimed to aid an infant industry, but also intended to stabilize conditions in a vital industry. ${ }^{97}$ Scuttling all economic controls might impair the consistency of schedules, stability of fares, levels of service, and safety of operations. Consequently, vigorous competition might revive past instabilities; feeble competition could result in a monopolistic industry free from public control. Either consequence would force renewed regulation in some form.

\section{A Proposal for Regulation}

An industry structure of competitive ${ }^{98}$ equals is an alternative to continued subsidization.99 In a sound airline regulatory scheme, competition should provide industry incentives to maximize revenue and minimize costs-at least two competitors must be after the same additional revenue, whether in

93. See discussion at pp. 1207-10 supra.

94. Three carriers serving the transcontinental market (American, United, and TWA) have assets over $\$ 100$ million. Northwest, the remaining transcontinental carrier, is only half that size, but it serves the more limited northern market. See route charts pp. 1203-4, and Aviation Week, Feb. 26, 1951, p. 110.

95. See notes 43,44 , supra, and text.

96. See Investigation of Local, Feeder, and Pick-up Air Service, 6 C.A.B. 1, 2 (1940).

97. See note 8 supra.

98. "[T]he basically competitive air transportation system as envisioned by the Civil Aeronautics Act of 1938 is in the public interest. In general, competition has been and continues to be one of the most important factors influencing the growth and development of this industry." Gill \& Bates, Ainline Competition 614 (1949).

99. The subsidy is no longer supporting the entire airline industry. Part of the subsidy underwrites the competition between the Big Four and the Little Twelve. The other part merely supports an industry of greater size and scope than airline customers support. For impassioned support of the "Bigger Outlook" in air transport policy, see Adams, The Air Route Pattern Problem, 17 J. AIr L. 127, 138 (1950). 
the form of subsidy or sales. At the same time, regulation should prevent competitive striving from becoming a costly luxury-it must be fostered only in markets that can support duplicating services without substantially increasing industry costs. 100

But even in such markets competition among numerous carriers may work harm. From a service improvement standpoint, two competitors can accomplish as much as three or four. ${ }^{101}$ Moreover, adding a third or fourth competitor may actually lower the overall level of service in a given market. ${ }^{102}$ When each competitor's maximum market share is limited by numerous rivals, all may shift service emphasis to develop less competitive areas. ${ }^{103}$ Competition in the airline industry, therefore, tends to operate in an oligopoly setting..$^{104}$ If this limited type of competition is to be preserved, the present imbalance of economic power between Big Four and Little Twelve must be redressed.

Compulsory mergers of the small lines can achieve competitive equality. ${ }^{105}$ To be effective, a merger program should create about eight firms. Four

100. This, of course, does not mean that only runs able to support numerous flights should be competitive. In a competitive capitalist economy, the maintenance of competitive incentives in itself obviously has some value for which either the government or the consumer should be reasonably expected to pay. Cf. United States v. Aluminum Co. of America, 148 F.2d 416, 429 (2d Cir. 1945). The problem should be approached in the light of the need for additional competition, its probable cost, and the area's traffic potential.

101. See Gill \& Bates, Airline Competitron 627 (1949).

102. See id. at 627 .

103. For example, "airline competition was an important influence in improving the quality of service offered the Chicago-Washington air traveler during the twelve years 1934-1946. During 1947 and 1948, however, [after non-stop authorizations were increased from one to four] the excessive competition on this segment caused a decline in service quality, evinced by a marked instability of schedule patterns offered by the four competitors during this period." Id. at 345-6.

104. See Hearings, supra note 21 , at 2119. For an excellent analysis of oligopoly market structures, consult FenLNER, Competirion Axrong the Few (1950) passim.

105. At least one member of the CAB, Vice-Chairman Ryan, has expressed doubts that the Board has the statutory power to force mergers. Aviation Week, June 18, 1951, p. 86. This point of view seems unnecessarily conservative. There are several possible avenues of approach under the Act. Among them, Section 401(h) seems the most promising :

"The Board may alter, amend, modify, or suspend any such certificate, in whole or in part, if the public convenience and necessity so require. . . " 52 Stat. 973, 989 (1938), 49 U.S.C. \$ 481 (1946).

This authorization should be broad enough to allow the $\mathrm{CAB}$ to reshuffle routes and companies. See also note 115 infra.

In addition the Board could suggest particular mergers and make the concerned carriers' mail pay contingent on effectuation. For an examination of these and other possibilities not involving an amendment to the Act, see Adams, The Air Route Pattern Problem 17 J. ARR L. 127, 137 (1950).

This merger program should not encounter any difficulties under the antitrust laws. Sec. 494 of the Act, 52 StAT. 973, 1004 (1938), 49 U.S.C. $\$ 499$ (1946) exempts airlines 
large, new firms geared to the size of the Big Four could be carved out of the Little Twelve. This new industry structure should provide four east-west and four north-south systems. ${ }^{106}$ Significantly, at least two carriers of equal strength would compete in every market capable of supporting more than a single airline. ${ }^{107}$ Such equality must be the keystone of any regulatory plan which compels service to uneconomic areas and fosters competition in others.

operating under $\mathrm{CAB}$ orders from antitrust prosecutions. Some doubt exists, however, concerning the limits of the airlines' immunity. See Note, Judicial Application of Antitrust Law to Regulated Industries, 64 HARv. L. REv. 1154 (1951); S.S.W. Inc. v. Air Transport Ass'n of America, 20 U.S.L. WeEK 2022 (D.C. Cir. July 17, 1951).

In any event the mergers contemplated here should not run afoul of the new Clayton Act $\$ 7$, Pub. L. No. 899, 81st Cong., 2d Sess. \$7 (1950), which simply prohibits mergers or acquisitions when the effect "may be to substantially lessen competition." See Note, 64 HARv. L. REV. 1212 (1951). The prime motive in suggesting airline mergers is to increase effective competition.

106. The general outline of such a program might embody the following changes: On the east coast the systems of National, Colonial, Northeast and Capital could be combined, see charts, pp. 1203-4. This would provide an integrated route pattern roughly comparable to Eastern in size and depth. The principal revenue producing markets would be Chicago-Washington, New York-Miami, and Boston-New York. The seasonality problems of Northeast, National and Colonial (note 67 supra) would virtually be eliminated. Furthermore, the equipment depth of the integrated system would allow it to compete effectively in heavy markets where these lines have been running a poor second to the Big Four.

On the West coast Western could be made part of Northwest, see charts, pp. 1203-4. This system would cover the northern transcontinental route to Seattle, the Pacific coast from Seattle to San Diego and the northern trans-Pacific run to the Orient via Alaska. The principal supporting runs would be San Francisco-Los Angeles, and Seattle-New York via Chicago and Minneapolis-St. Paul. The main purpose of the merger would be to give Western sufficient long haul depth to compete effectively with United between San Francisco and Seattle. It would also mitigate Northwest's seasonality problems in the northern areas by giving it entrance to the dense and stable San Francisco-Los Angeles market.

Delta Airlines, one of the most promising of the Little Twelve in terms of costs as well as revenue, see note 58 supra and charts pp. 1203-4, could be given a southern transcontinental route from Florida to California. Currently this route is served only by an equipment interchange between Delta and American at Dallas. Also, Delta could operate any of the Inland, Mid-Continent and Continental routes in the southern area with an east-west flow, see charts, pp. 1203-4. Delta's key revenue market now is ChicagoMiami via Atlanta. This would leave Delta a little leaner than most of the remaining seven systems. But the fact that Delta has key routes in the rapidly developing southern area where competition from surface transportation is at a minimum should make this only a temporary disadvantage.

The remaining two carriers, Chicago \& Southern and Braniff might provide the nucleus for competitive systems down the central section of the country from Chicago and Detroit to New Orleans and southern Texas. They could incorporate any routes of Inland, Mid-Continent, and Continental with a north-south flow.

107. See Healy, Workable Competition in Air Transportation, 35 Asr. EcoN. REv. SuPP. 229 (1945) for a further economic analysis, resulting in proposed industry restructuring. 
Coupled with this merger program should be a revision of the subsidy formula and administration. Under the present system, payments are essentially on a cost-plus basis. In an industry of approximate equals, desired industry size rather than individual carrier need should determine the total subsidy grant. Subsidy payments keyed to performance could be based on each carrier's passenger miles flown. ${ }^{108}$ Manipulating the subsidy total could flexibly keep the industry at desired size. Rewarding carriers for service rather than need would leave full play to competitive profit incentives. ${ }^{109}$ Airlines thus would be left free to experiment with adjusting fares ${ }^{110}$ to demand elasticity for air travel should conditions make it possible. ${ }^{111}$ Because airline competition is competition among the few and lean areas cannot economically be made competitive, ${ }^{112}$ ceilings on fares might have to be imposed..$^{113}$ The subsidy would be computed periodically on the basis of total industry profit. Once total profit exceeded a certain rate of return-say $7 \%$ of the industry's invested capital ${ }^{114}$ - the total industry subsidy could be trimmed to size. Under this system, a carrier not making profits would either not be a structural equal of his competitor or its management wauld be less efficient.

108. Compare present subsidy administration, notes $45-52$ supra and text.

109. Since sales performance rather than need would determine the amount of the subsidy, each carrier would strive to maximize output. Subsidies would not cover operating losses beyond the fixed subsidy rate. Thus sales below cost would result in uncompensated losses to the company. There would thus be no need to fear that price competition would be paid for by the government.

110. Because the subsidy would be geared to passenger miles flown, managements will try to find the most advantageous price relationship in terms of fare and subsidy income. While inertia may be a substantial barrier to such experimentation, at least the subsidy will not discourage it-a primary objection to the current system. See notes 45-52 supra and text.

111. See note 89 supra. In this connection it should be noted that private entrepreneurs tend to underestimate demand elasticity. The TVA and Bonneville experiments in electricity have indicated this. See Lewis, The Government as Competitor: The Effect on Private Investment, 29 Ax. Econ. Rev. 286, 295-6 (1939).

112. Even under the proposed reorganization there will be areas served by only one carrier.

113. This may be necessary on non-competitive segments of each carrier's system. Even on the competitive segments, some control might be necessary. When only two competitors constitute a market the adverse effect on the carrier not reducing prices is immediately felt. Consequently retaliation is almost a certainty. Both competitors realize this and may refrain from cutting prices because of the fear that both will end up doing substantially the same volume of business at a lower price. See generally, SAMruelson, Economics, An Introductory Analysis (1948). Thus, in the absence of CAB prodding, technological cost reductions might not be passed on to the airline consumer.

Moreover, in the absence of a watchdog the two firms may informally agree to either hold prices or raise them.

114. In fixing mail pay rates the $\mathrm{CAB}$ attempts to award a $7 \%$ retur' 3 on invested capital. Hearings, supra note 21, at 2126. 
Carriers' certificates renewable every four years ${ }^{115}$ could provide a mechanism for replacing profit stragglers. By staggering initial certifications, a pair of competitors would be up for renewal each year. At such time, both carriers' activities could be measured and reviewed. Necessary route equalization could be effected. ${ }^{116}$ Also at renewal hearings any groups desiring entry to the industry could demonstrate their ability to operate one of the systems more efficiently. If successful, the new group would be awarded the certificate for the next four years. Attendant publicity, normal profit incentives, and the test of periodic renewal would combine to force performance as efficient as in unregulated competitive industries. ${ }^{117}$

\section{Conclusion}

In the air transport industry, regulation and competition must be developed into a coherent pattern to secure maximum incentives for low cost efficient service at desired industry size. The current $C A B$ route freeze is not likely to reduce the industry's subsidy need nor to promote sound industry growth.

Economic equality among carriers is essential to success of the Civil Aeronautics Act's policy of limited competition. Existing size disparity compels heavy subsidy payments to smaller carriers. Moreover, competitive imbalance burdens the public with unnecessarily high costs for air service. A bold program of compulsory mergers accompanied by subsidy reform is needed to remove blocks to efficient performance.

115. Under the present system the certificates are "permanent". Presumably this is the reason for some doubt that the CAB has the power to force mergers. But "permanent" in this context means merely that they are not periodically renewable. The CAB has never doubted its authority to modify the value of a particular certificate either by certificating competitors into a previously exclusive territory or by altering the mail rate. In fact, the Board on one occasion initiated dismemberment proceedings against an airline in serious financial difficulties. In re National Airlines, Inc. 10 C.A.B. 8 (1948). For a discussion of the legal status of airline certificates, see Note, 48 CoL. L. REv. 88 (1948).

116. This renewal requirement would not create long term financing difficulties since route modifications should be of a very minor character if the systems initially were constructed as equals. Furthermore, knowledge on the part of investors that the CAB will periodically examine managerial efficiency should more than compensate for any investment dislocation caused by route modifications.

117. The feeder lines are not a part of this proposal. The future of feeders depends essentially on the development of efficient short haul aircraft. Until such time, the CAB attitude of experimentation seems reasonable. Likewise, a subsidy geared to need is proper at this stage of feeder development. Whenever technological advances make feeder-type air services potentially self-sufficient, the same general regulatory principleslimited competition, size equality, and a subsidy geared to passenger miles flown-should be applicable to this segment of the industry. 